Acta regionalia et environmentalica 2

Nitra, Slovaca Universitas Agriculturae Nitriae, 2014, p. 64-70

\title{
REGIONAL DISPARITIES AND THEIR REASONS. COMPARATIVE ANALYSIS OF SLOVAKIA AND HUNGARY
}

\author{
Martin MARIŠ \\ Slovak University of Agriculture in Nitra, Slovakia
}

\begin{abstract}
Paper is focused on regional disparities and structural changes of economies of the V4 countries: the Slovak Republic and Hungary. The results have shown increasing regional differences between the capital regions, including their adjacent areas and the rest of the countries in case of both countries, based on empirical data and documented by the Lorenz curve. We can also observe an increasing difference between Western and Eastern areas of both countries. In terms of structural changes in the economy during the analyzed period 2001-2009, we can see a substantial shift in employment from primary sector (agriculture etc.) mainly to tertiary sector (services etc.) and also to secondary sector (industry etc.). The results are based on empirical data from secondary sources.
\end{abstract}

Keywords: production factors, centrally planned economy, market economy, structural changes

The Slovak Republic and Hungary - former satellite states of the Soviet Union - had during their transition periods overcome a number of obstacles in the trajectory of growth and competitiveness building (Enyedi, 1990). After 1989, both countries set off on the path of building market oriented economies, which required substantial reforms that significantly affected the lives of their citizens. In this sense, we particularly have in mind the structural changes in the economies as well as the structural changes on the labour market. The economic structure of the countries as well as the labour market were submitted to a process of self-adaptation in response to competitive pressures of emerging markets and advanced economies. An essential part of building a market economy was unlocking of the macroeconomic environment, accompanied by privatization, liberalization and state deregulation. The macroeconomic effects of these market reforms significantly affected both economies in some areas in terms of inflexible adaptation of their production factors.

In Slovakia, the regional imbalance began its rising in the accelerated pace in the first half of 90 's. The main driver of the imbalance in the territory became the region of Bratislava, which significantly outpaces the other regions of Slovakia by its macroeconomic performance (OECD, 2011). In Hungary, since 90's regional imbalance has been rising stable, led by thecentral region of Hungary - Budapest, Pest (Közép-Magyarország) and conversely by the lagging ones - Del-Dunantul, Del-Alfold and Eszak-Magyarorszag (OECD, 2011).

In the current era of globalization, we should argue that regions have become more important than entire nations in terms of creation of economic growth (Krugman, 1997), in that the business environment is highly sensitive to regional conditions and so the region becomes a more appropriate unit of analysis than a nation itself (Stam, 2008). 
Slovakia. As the indicator we consider regional GDP/capita in 2009 for the regions of both countries.

The hypothesis is checked for the sample of regions of Slovakia and Hungary. In essence, the analysis is based on the assessment of descriptive characteristics of the sample - moments. In practice, we used the third moment of standard variable skewness $\mu_{t .3}$. To test normality of the distribution of the sample, we used the test for normality based on selection skews and D'Agostino test.

The selection skews can be characterized as follows:

$$
A_{3}=\frac{\frac{1}{n} \sum_{i=1}^{n}\left(X_{1}-M\right)^{3}}{\left[\sqrt{\frac{1}{n} \sum_{i=1}^{n}\left(X_{1}-M\right)^{2}}\right]^{3}}
$$

It can be shown that the choice of the normal distribution applies:

$$
E\left(A_{3}\right)=0, \quad D\left(A_{3}\right)=\frac{6(n-2)}{(n+1) \cdot(n+3)}
$$

A test based on skews rejects the hypothesis of normal distribution on the asymptotic significance level $\alpha$ if:

$$
U=\frac{\mid}{\sqrt{D(A)}} \geq u
$$

The D'Agostino test can be characterized by using auxiliary variables as follows:

$$
\begin{gathered}
b=\frac{3\left(n^{2}+27 n-70\right) \cdot(n+1) \cdot(n+3)}{(n-2) \cdot(n+5) \cdot(n+7) \cdot(n+9)} \\
W^{2}=\sqrt{2(b-1)}-1 \\
d=\frac{1}{\sqrt{\ln W}}, a=\sqrt{\frac{2}{W^{2}-1}}
\end{gathered}
$$

Test characteristics is:

$$
Z_{3}=d \cdot \ln \left[\frac{U_{3}}{a}+\sqrt{\left(\frac{U_{3}}{a}\right)^{2}+1}\right]
$$

It is valid that it has approximately normal distribution $N(0,1)$ for $n>8$ we reject the hypothesis of normal distribution if $\left|Z_{3}\right| \geq u_{1-\frac{\alpha}{2}}$.

Basically, we would like to demonstrate if the sample meets the assumption of normal distribution. Normal distribution assumes that the statistical units of the surveyed random variable will be concentrated in the vicinity of the sample characteristics, which may be average or median. This case will be approximated as a balance in the area for the Slovakia and for Hungary. If the normal distribution is valid, it could be considered that the imbalance between the regions in terms of the ratio of GDP/ capita is statistically insignificant. We formulated the following hypothesis:

$\mathrm{H}_{0}=$ in the regional structure of Slovakia and Hungary there is no statistically proven more significant imbalance between regions in terms of the ratio GDP/ capita.

$\mathrm{H}_{1}$ = in the regional structure of the Slovakia and Hungary, there is a statistically proven more significant imbalance between regions in terms of the ratio GDP/ capita.

\section{Results and discussion}

\section{Regional disparities in the regional structure of Slovakia and Hungary}

One aspect of the analysis of our sample (basic set of regions on NUTSIII level) is the degree of concentration of selected variable (regional GDP) directly in statistical units (regions). For measuring the degree of concentration, we accept the following:

Coefficient of concentration is the share of space bounded by the Lorenz curve and the diagonal of the space of the triangle, bounded by diagonal, $x$-axis and running perpendicular to the $x$ axis in 1:

$$
K_{k}=\frac{P}{T}=\frac{0.5-S}{0.5}=1-2 S
$$

where:

$P \quad$ - the space bounded by the diagonal and the Lorenz curve

$T$ - space of triangle; $T=0.5$ $S=T-P$

Space $S$ should be calculated as a sum of spaces of rectangles, whose sides are $f_{i}$ and $\left.\frac{1}{2}\left(Z_{i-1}\right)+Z_{i}\right)$, by substituting we get:

$$
K_{k}=1-\sum_{i=1}^{m} f_{i}\left(Z_{i-1}+Z_{i}\right)
$$

Concentration ratio is an average of the relative differences between the cumulative relative frequencies in groups and cumulative shares of groups in the cumulative sum of the character values in the sample set:

$$
P_{k}=\frac{\sum_{i=1}^{m-1} D_{i} F_{i}}{\sum_{i=1}^{m-1} F_{i}}=\frac{\sum_{i=1}^{m-1} \frac{F_{i}-Z_{i}}{F_{i}} F_{i}}{\sum_{i=1}^{m-1} F_{i}}=\frac{\sum_{i=1}^{m-1}\left(F_{i}-Z_{i}\right)}{\sum_{i=1}^{m-1} F_{i}}
$$

For both rates, assuming values from the interval $(0,1)$, it is valid that the more they lean to one, the more stronger is the concentration.

The results show moderate degree of concentration in both indicators and in both countries, which indicates moderate differences in terms of GDP per capita in the majority of regions. These results are also confirmed by the Lorenz curve, in both cases, at low values the space between the Lorenz curve and diagonal of the triangle is narrow, the curve is near to the equality line which represents the regions with the similar level of GDP. At 


\section{In case of Slovakia}

Table 1 Regions of Slovakia listed by regional GDP and population

\begin{tabular}{|l||c|c|c|c|c|c|c|}
\hline $\begin{array}{l}\text { Spread of the } \\
\text { Med. in \% }\end{array}$ & $\begin{array}{c}\text { Number of } \\
\text { inhabitans }\end{array}$ & $\begin{array}{c}\text { Regional GDP } \\
\text { in mil. USD }\end{array}$ & $\begin{array}{c}\text { Relative } \\
\text { frequency in \% }\end{array}$ & $\begin{array}{c}\text { Cummulative } \\
\text { relative frequnecy. } F \boldsymbol{i}\end{array}$ & $\begin{array}{c}\text { Share of GDP } \\
\text { on } \mathbf{Z i}\end{array}$ & $\boldsymbol{F i}-\mathbf{Z i}$ & $\left(Z_{\boldsymbol{i}-\mathbf{1}}+\boldsymbol{Z}_{\boldsymbol{i}}\right) \boldsymbol{f}_{\boldsymbol{i}}$ \\
\hline \hline $\mathbf{0 - 8 0}$ & $1,460,197$ & 19,717 & 26.92 & 26.92 & 17.273 & 9.64 & 464.92 \\
\hline $\mathbf{8 0 - 1 0 0}$ & $2,074,836$ & 36,581 & 38.25 & 65.16 & 49.320 & 15.84 & $2,546.92$ \\
\hline $\mathbf{1 0 0 - 1 2 0}$ & $1,267,186$ & 25,871 & 23.36 & 88.52 & 71.984 & 16.54 & $2,833.49$ \\
\hline$>\mathbf{1 2 0}$ & $\mathbf{6 2 2 , 7 0 6}$ & 31,980 & 11.48 & 100.00 & 100.000 & $\times$ & $1,974.14$ \\
\hline Total & $\mathbf{5 , 4 2 4 , 9 2 5}$ & $\mathbf{1 1 4 , 1 4 8}$ & $\mathbf{1 0 0 . 0 0}$ & $\times$ & $\times$ & $\mathbf{4 2 . 0 2}$ & $\mathbf{7 , 8 1 9 . 4 7}$ \\
\hline & & & & $\mathbf{1 8 0 . 6 0}$ & & & \\
\hline
\end{tabular}

$P_{k}=\frac{54.7938}{231.5704}=0.24$

The sum of the column no. 8 of table 1 , divides $100^{2}$, therefore we make the calculation in $\%: K_{k}=1-0.7818 \cong 0.22$

Source: own calculations, based on the data from the statistical database REGDAT

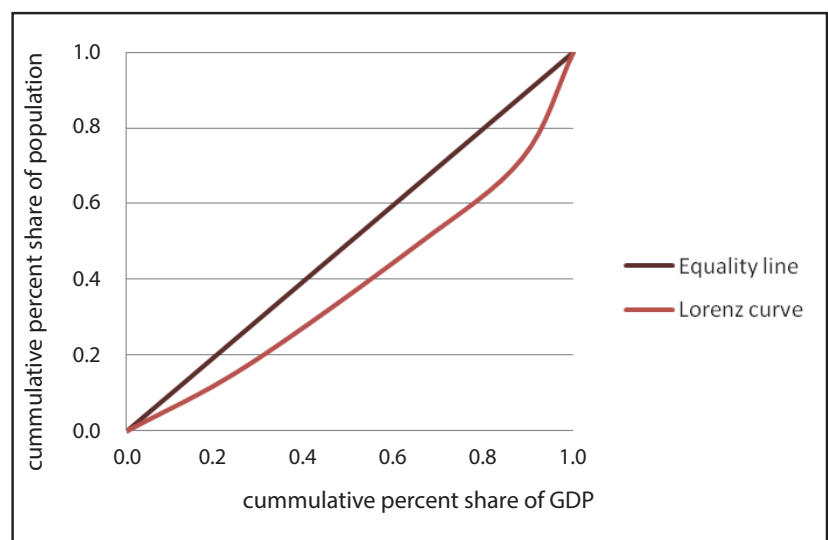

Figure 1 The Lorenz curve, Slovakia case Source: own calculations

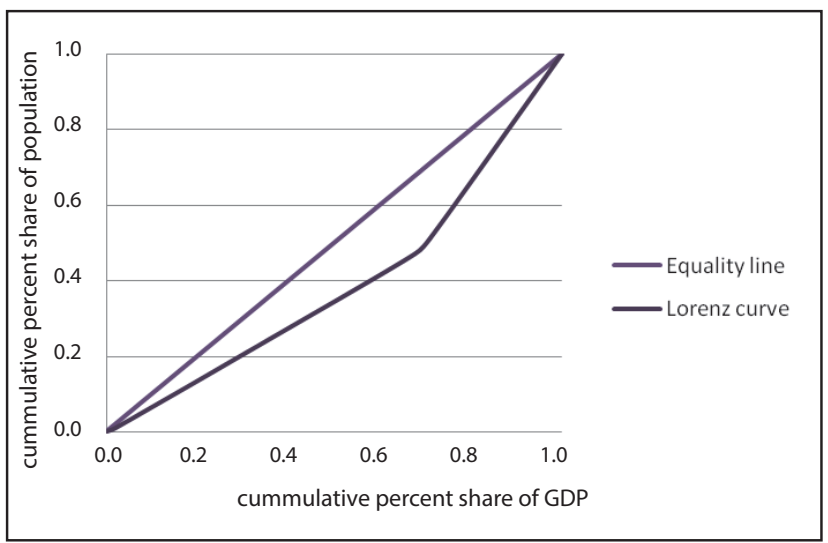

Figure 2 The Lorenz curve, Hungary case Source: own calculations

\section{In case of Hungary}

Table 2 Regions of Hungary listed by regional GDP and population

\begin{tabular}{|c|c|c|c|c|c|c|c|}
\hline $\begin{array}{l}\text { Spread of the } \\
\text { Med. In \% }\end{array}$ & $\begin{array}{l}\text { Number of } \\
\text { inhabitans }\end{array}$ & $\begin{array}{l}\text { Regional GDP } \\
\text { in mil. USD }\end{array}$ & $\begin{array}{c}\text { Relative } \\
\text { frequency in \% }\end{array}$ & $\begin{array}{c}\text { Cummulative relative } \\
\text { frequnecy } \mathrm{Fi}\end{array}$ & $\begin{array}{l}\text { Share of } \\
\text { GDP on Zi }\end{array}$ & $F i-Z i$ & $\left(Z_{i-1}+Z_{i}\right) f_{i}$ \\
\hline $0-50$ & 207,637 & 1,743 & 2.07 & 2.07 & 0.949648 & 1.12 & 1.9657315 \\
\hline 50-100 & $2,945,177$ & 37,481 & 29.36 & 31.43 & 21.370 & 10.06 & 655.33 \\
\hline $100-150$ & $3,505,628$ & 45,229 & 34.95 & 66.38 & 46.01 & 20.37 & 2354.88 \\
\hline $150-200$ & 447,033 & 8,772 & 4.46 & 70.84 & 50.79 & 20.04 & 431.41 \\
\hline$>200$ & $2,925,500$ & 90,321 & 29.16 & 100.00 & 100.00 & $x$ & 4397.78 \\
\hline \multirow[t]{2}{*}{ Total } & $10,030,975$ & 183,546 & 100.00 & $x$ & $x$ & 51.59 & 7841.36 \\
\hline & & & & 170.71 & & & \\
\hline
\end{tabular}

$P_{k}=\frac{83.0488}{283.7128}=0.293$

The same approach: $K_{k}=1-0.7544,4589 \cong 0.2181$

Source: own calculations, based on the data from statistical database of Hungary, www.ksh.hu

high values, the space is wider and the curve is leaning to 1. Higher values are represented by the most developed regions of Bratislava in Slovakian case and Budapest in Hungarian case, with a significantly higher share on GDP compared to other regions, which means these are extreme values.
Thus, finally we can state that the regional disparities are most significant between the capital regions and the rest of both countries.

When testing the hypothesis of normally distributed statistical sample describing regional GDP/capita at Nuts III of Hungary and Slovakia countries, we proceeded as follows. In Slovakia, we obtained the following results: 
Skews:

$$
A_{3} \doteq \frac{\frac{1}{8} \cdot 7.096 \cdot 10^{12}}{\left[\sqrt{\frac{1}{8} \cdot 3.9 \cdot 10^{8}}\right]^{3}} \doteq \frac{7.096 \cdot 10^{12}}{3.403 \cdot 10^{11}} \doteq 2.606
$$

Variance:

$$
D\left(A_{3}\right)=\frac{6(8-2)}{(8+1) \cdot(8+3)}=0.36
$$

Test based on skewness:

$$
U_{3}=\frac{|2.606|}{\sqrt{0.973}}=2.677 \geq 1.96
$$

D’Agostino test:

$$
\begin{gathered}
b=\frac{3\left(n^{2}+27 n-70\right) \cdot(n+1) \cdot(n+3)}{(n-2) \cdot(n+5) \cdot(n+7) \cdot(n+9)}=3.135 \\
W^{2}=\sqrt{2(b-1)}-1=1.066 \\
d=\frac{1}{\sqrt{\ln W}}=5,563 ; a=\sqrt{\frac{2}{W^{2}-1}}=5.473 \\
Z_{3}=d \cdot \ln =\left[\frac{U_{3}}{a}+\sqrt{\left(\frac{U_{3}}{a}\right)^{2}+1}\right]=2.622 \geq 1.96
\end{gathered}
$$

In Hungary, we obtained the following results: Skews:

$$
A_{3} \doteq \frac{\frac{1}{20} \cdot 2.062 \cdot 10^{13}}{\left[\sqrt{\frac{1}{8} \cdot 1.107 \cdot 10^{9}}\right]^{3}} \doteq \frac{1.031 \cdot 10^{12}}{4.12 \cdot 10^{11}} \doteq 2.502
$$

Variance:

$$
D\left(A_{3}\right)=\frac{6(20-2)}{(20+1) \cdot(20+3)}=0.22
$$

Test based on skewness:

$$
U_{3}=\frac{|2.502|}{\sqrt{0.559}}=3.345 \geq 1.96
$$

D’Agostino test:

$$
\begin{gathered}
b=\frac{3\left(n^{2}+27 n-70\right) \cdot(n+1) \cdot(n+3)}{(n-2) \cdot(n+5) \cdot(n+7) \cdot(n+9)}=3.577 \\
W^{2}=\sqrt{2(b-1)}-1=1.27 \\
d=\frac{1}{\sqrt{\ln W}}=2.88 ; a=\sqrt{\frac{2}{W^{2}-1}}=2.718 \\
Z_{3}=d \cdot \ln =\left[\frac{U_{3}}{a}+\sqrt{\left(\frac{U_{3}}{a}\right)^{2}+1}\right]=2.922 \geq 1.96
\end{gathered}
$$

Empirical results have shown us in both cases that the previously calculated rate of skewness indicates a higher degree of skewness. The sample is skewed to the left-side asymmetry, which means that the frequency is more concentrated at lower values and characters towards higher values are declining. That selection and characterization together with the test indicates a relatively heterogeneous set that speaks about spatial imbalance in the territory of the regions of Slovakia and Hungary. In conclusion, the results of both test values, outweigh the tabular value of the normal distribution $u_{1-\frac{1}{\alpha}}=1.96$; i.e. on the asymptotic significance level $\alpha=0.05$ the alternative hypothesis of the existence of statistically significant imbalances in the overall regional structure of the V4 countries is accepted. Furthermore, according to the data resulting from the evaluation of the regional imbalance OECD regions of Slovakia and Hungary in early 1990, regional imbalance ranged from 0.08 to 0.15 points, according to index imbalance GDP/capita on NUTS Il level (OECD, 2011).

\section{Structural change analysis}

The terms like "structure" and "structural changes" have become widely used in the field of economic research, although in different meanings and interpretations. In economic development and economic history, structural change is generally seen as a "change in the arrangement of the productive sectors of the economy and changes in the distribution of production factors between different sectors of the economy, different professions, different geographical regions and different kinds of products" (Machlup, 1990).

In general, structural changes are the effect of a change in technology and society. Technological progress and innovation affects changes in economic activities in the horizontal direction, and a social change and political ideologies affect changes in economic activities in the vertical direction.

Practically, structural changes are tightly connected to structural unemployment, when there is a dip in demand for certain important employment sector. Local labour markets are unable to face these changes in a sufficient pace and adapt themselves. Since that the labour market is not homogenous, structural unemployment is also the problem of advanced economies and in combination with the inflexible labour market, high labour costs and often with strong trade unions, regional economy could decay into structural depression personificated by the outflow of capital and labour.

The initial labour market conditions varied across the CEE countries. While it was functioning, the Soviet-type economic system was characterized by full employment of labour force and centrally set wages, prices and output targets for state-owned enterprises. Income distribution was maintained at relatively egalitarian levels, most people were required to work and enterprises were allocated funds to provide needed jobs (Svejnar, 2002). Centrally planned economics allowed specialization of labour in some branches of the economy, based on unreal market needs. Over 1989 in a relatively turbulent macroeconomic situation characterized by the disintegration of internal and external markets, liquidation of many enterprises started, mainly the ones connected with traditional branches of a centrally planned economy like: mining, heavy industry, 
agriculture etc. which partially caused the structural longterm unemployment.

In this thematic topic we analyze the effects of structural changes in the labour market in Slovakia and Hungary in two comparable periods: 2001-2009, due to access data from both countries. We calculate the effect of these changes by using the shift-share analysis, based on:

$$
e_{i}^{t+n}-e_{i}^{t}=\text { share change }+ \text { mix change }+ \text { shift change (1.11) }
$$

This says that change in employment in the study area's ith activity from time $t$ to time $t+n$ can be measured or more formally:

$$
\begin{aligned}
e_{i}^{t+n}-e_{i}^{t}=e_{i}^{t} & {\left[\frac{E^{t+n}}{E^{t}}-1\right]+e_{i}^{t}\left[\frac{E_{i}^{t+n}}{E_{i}^{t}}-\frac{E^{t+n}}{E^{t}}\right]+} \\
& +e_{i}^{t}\left[\frac{e_{i}^{t+n}}{e_{i}^{t}}+\frac{E_{i}^{t+n}}{E_{i}^{t}}\right]
\end{aligned}
$$

We avoid calculations by using absolute values, value of we put equal to 1 and the result is a coefficient.

The total employment in Slovakia during the period of 2001-2009 increased, but in each sector, employment evolved differently.

The results show relatively substantial decline in employment in the agricultural sector in all regions according to the coefficient of structural change. The compound of mix change shows that the rate of change in employment in the agricultural sector (in terms of decline) was higher than the rate of change in the total employment (in terms of growth), and the rate of change in employment in the compound of shift change in all regions was below or above the level of the change in national employment in the sector. The total employment in the agricultural sector in the analyzed period was declining faster than e ttotal employment growth in the country so the sector of agriculture is in retreat. The most afflicted regions are: the Trnava region, the Nitra region and the Žilina region and the least is the Prešov region.

The sector of industry denoted the growth in some regions and in some regions employment declined,

\section{In case of Slovakia}

Table 3 Structural changes analysis in regions of Slovakia in time period of 2001-2009

\begin{tabular}{|l||c|c|c|c|c|c|c|c|c|c|c|c|}
\hline \multicolumn{1}{|c||}{} & \multicolumn{5}{|c|}{ Agriculture } & \multicolumn{3}{c|}{ Industry } & \multicolumn{4}{c|}{ Services } \\
\hline Region & coefficient & $\begin{array}{c}\text { share } \\
\text { change }\end{array}$ & $\begin{array}{c}\text { mix } \\
\text { change }\end{array}$ & $\begin{array}{c}\text { shift } \\
\text { change }\end{array}$ & coefficient & $\begin{array}{c}\text { share } \\
\text { change }\end{array}$ & $\begin{array}{c}\text { mix } \\
\text { change }\end{array}$ & $\begin{array}{c}\text { shift } \\
\text { change }\end{array}$ & coefficient & $\begin{array}{c}\text { share } \\
\text { change }\end{array}$ & $\begin{array}{c}\text { mix } \\
\text { change }\end{array}$ & $\begin{array}{c}\text { shift } \\
\text { change }\end{array}$ \\
\hline BSK & -0.2823 & 0.0994 & -0.3663 & -0.0154 & -0.1233 & 0.0994 & -0.0728 & -0.1499 & 0.0371 & 0.0994 & 0.0781 & -0.1405 \\
\hline TTSK & -0.3427 & 0.0994 & -0.3663 & -0.0758 & 0.3957 & 0.0994 & -0.0728 & 0.3692 & 0.1729 & 0.0994 & 0.0781 & -0.0047 \\
\hline TSK & -0.2391 & 0.0994 & -0.3663 & 0.0278 & 0.0205 & 0.0994 & -0.0728 & -0.0061 & 0.1826 & 0.0994 & 0.0781 & 0.0051 \\
\hline NSK & -0.3016 & 0.0994 & -0.3663 & -0.0347 & 0.1181 & 0.0994 & -0.0728 & 0.0915 & -0.0033 & 0.0994 & 0.0781 & -0.1809 \\
\hline ZSK & -0.3208 & 0.0994 & -0.3663 & -0.0539 & 0.062 & 0.0994 & -0.0728 & 0.0354 & 0.1167 & 0.0994 & 0.0781 & -0.0608 \\
\hline BBSK & -0.2825 & 0.0994 & -0.3663 & -0.0156 & -0.19 & 0.0994 & -0.0728 & -0.2165 & 0.1503 & 0.0994 & 0.0781 & -0.0273 \\
\hline PSK & -0.135 & 0.0994 & -0.3663 & 0.1319 & -0.0061 & 0.0994 & -0.0728 & -0.0327 & 0.1015 & 0.0994 & 0.0781 & -0.076 \\
\hline KSK & -0.2221 & 0.0994 & -0.3663 & 0.0448 & -0.0372 & 0.0994 & -0.0728 & -0.0637 & 0.1239 & 0.0994 & 0.0781 & -0.0536 \\
\hline
\end{tabular}

Note: BSK - Bratislava region, TTSK - Trnava region, TSK - Trencin region, NSK - Nitra region, ZSK - Žilina region, BBSK - Banská Bystrica region, PSK - Prešov region, KSK - Košice region

Source: own calculations, based on the data from the statistical database REGDAT

\section{In case of Hungary}

Table 4 Structural changes analysis in regions of Hungary in time period of 2001-2009

\begin{tabular}{|l||c|c|c|c|c|c|c|c|c|c|c|c|}
\hline \multicolumn{1}{|c||}{} & \multicolumn{4}{c|}{ Agriculture } & \multicolumn{4}{c|}{ Industry } & \multicolumn{4}{c|}{ Services } \\
\hline Region & coefficient & $\begin{array}{c}\text { share } \\
\text { change }\end{array}$ & $\begin{array}{c}\text { mix } \\
\text { change }\end{array}$ & $\begin{array}{c}\text { shift } \\
\text { change }\end{array}$ & coefficient & $\begin{array}{c}\text { share } \\
\text { change }\end{array}$ & $\begin{array}{c}\text { mix } \\
\text { change }\end{array}$ & $\begin{array}{c}\text { shift } \\
\text { change }\end{array}$ & coefficient & $\begin{array}{c}\text { share } \\
\text { change }\end{array}$ & $\begin{array}{c}\text { mix } \\
\text { change }\end{array}$ & $\begin{array}{c}\text { shift } \\
\text { change }\end{array}$ \\
\hline \hline CH & -0.4513 & -0.0223 & -0.2553 & -0.174 & -0.081 & -0.0223 & -0.0873 & 0.0292 & 0.115 & -0.0223 & 0.0774 & 0.0599 \\
\hline CT & -0.3049 & -0.0223 & -0.2553 & -0.027 & -0.057 & -0.0223 & -0.0873 & 0.0531 & 0.0154 & -0.0223 & 0.0774 & -0.0396 \\
\hline WT & -0.0645 & -0.0223 & -0.2553 & 0.2132 & -0.124 & -0.0223 & -0.0873 & -0.0139 & 0.0094 & -0.0223 & 0.0774 & -0.0456 \\
\hline ST & -0.2217 & -0.0223 & -0.2553 & 0.0559 & -0.057 & -0.0223 & -0.0873 & 0.0526 & -0.0051 & -0.0223 & 0.0774 & -0.0602 \\
\hline NT & -0.3243 & -0.0223 & -0.2553 & -0.047 & -0.124 & -0.0223 & -0.0873 & -0.0139 & -0.0207 & -0.0223 & 0.0774 & -0.0758 \\
\hline NGP & -0.1912 & -0.0223 & -0.2553 & 0.0865 & -0.134 & -0.0223 & -0.0873 & -0.0245 & 0.0154 & -0.0223 & 0.0774 & -0.0397 \\
\hline SGP. & -0.3463 & -0.0223 & -0.2553 & -0.069 & -0.208 & -0.0223 & -0.0873 & -0.0981 & 0.0961 & -0.0223 & 0.0774 & 0.0411 \\
\hline
\end{tabular}

Note: CH - Central Hungary, CT - Central Transdanubia, WT - Western Transdanubia, ST - Southern Transdanubia, NT - Nothern Hungary, NGP - Nothern Great Plain, SGP - Southern Great Plain

Source: own calculations, based on the data from statistical database of Hungary, www.ksh.hu 
according to the coefficient of structural changes, however, the rate of change in employment by industrial sector (in terms of growth) increased less than the rate of change in the total employment (in terms of growth); (represented by mix change). The compound of shift change changed in regions individually, below or above the level of the change in national employment in the sector. The most progressive regions were: the Trnava region, the Nitra region and some regions denoted substantial decline: the Bratislava region and the Banská Bystrica region.

The sector of services denoted growth in all regions of Slovakia (except the region of Nitra), according to the coefficient of structural changes. The compound of mix change shows that the rate of change in employment in the service sector (growth) was higher than the change of the total employment (growth). So, the growth rate of the service sector was higher than the growth rate of the total employment in the country. The compound of shift change changed in regions individually, mostly below the national rate of growth in the sector of services. The most progressive regions are: the Trenčín region, the Trnava region and least the Bratislava region.

The total employment in Hungary during the period of 2001-2009 declined, but in each sector, employment evolved differently.

The employment in the agricultural sector noted substantial drop, represented by the coefficient of structural changes in all regions. The compound of mix change noted that the rate of change in employment of agricultural sector (in terms of decline) was even higher than the rate of change in the total employment (in terms of decline). The compound of shift-change changed (in terms of decline) in all regions individually, below or under the level of change in the national employment in the sector. Hence, the total employment in the agricultural sector in the analyzed period declined faster than the total employment in the country. The most afflicted regions are the Central Hungary, the Southern Great Plain and the Northern Hungary, the least is the Western Transdanubia.

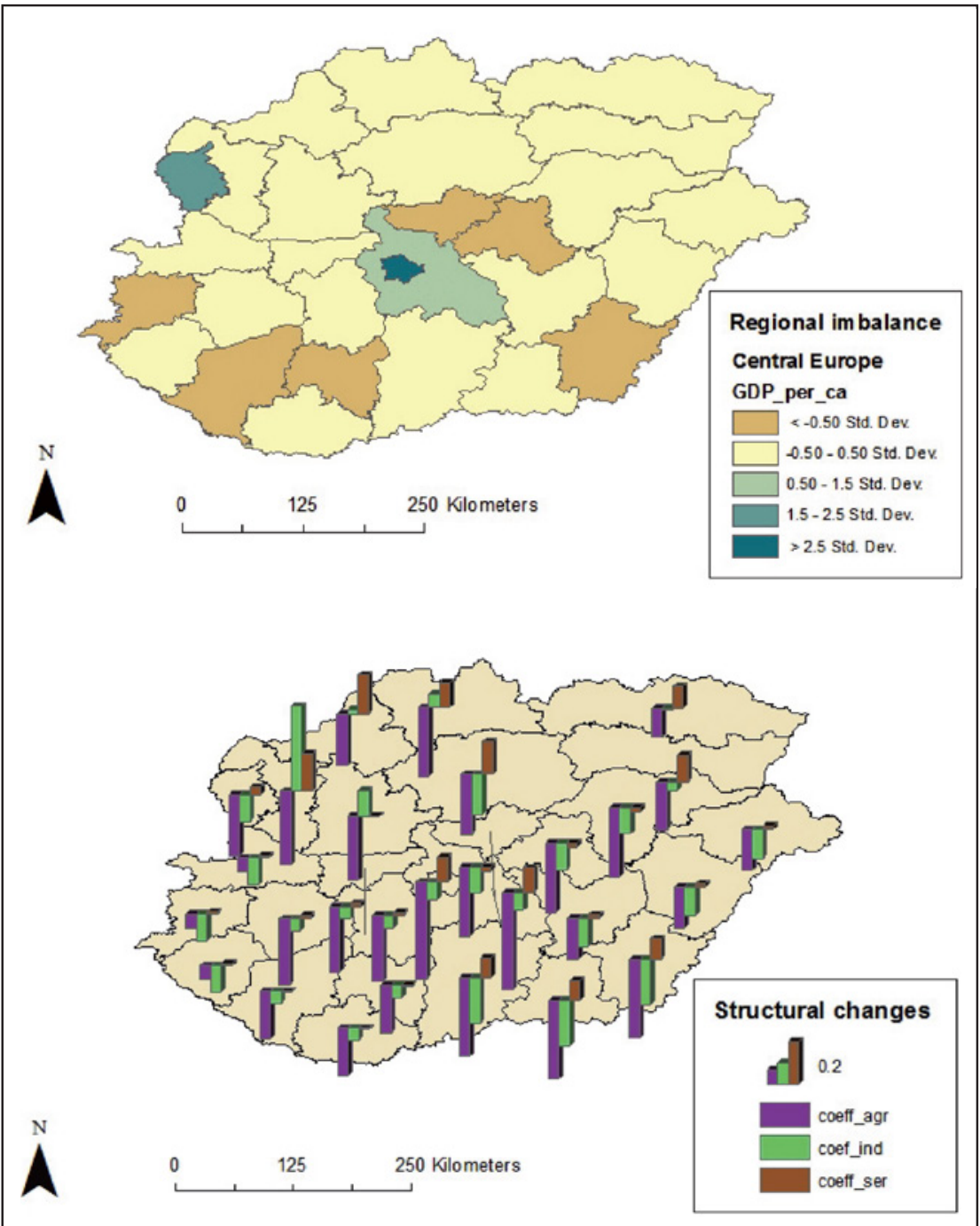

Figure 1 Regional imbalance and structural changes analysis, spatial perspective Source: own calculations

The sector of industry also noted a drop, represented by the coefficient of structural change in all regions. The compound of mix change also noted that the rate of change in employment by industrial sector (in terms of decline) was even higher than the rate of change in the total employment (in terms of decline). The compound of shiftchange, changed (in terms of decline) in all regions individually, below or under the level of change in the national employment in the sector. Thus, the total employment in the industrial sector in the analyzed period declined faster than the total employment in the country. The most afflicted regions were the Southern Great Plain and the Northern Great Plain, the least being the Southern Transdanubia, the Central-Transdanubia and the Central Hungary.
The sector of services noted growth in most regions of Hungary according to the coefficient of structural changes. The compound of mix changes also noted that change in employment in the service sector (in terms of growth) was evolving conversely compared to the total employment changes in the country (in terms of decline). The compound of shift-change changed (in terms of growth) in all regions, below or under the level of change in the total employment in the sector. Thus, the total employment in the service sector in the analyzed period was increasing, against the trend of decrease in the total employment in the country. Employment by sector was mostly rising in the Central Hungary and decreased in the Southern Transdanubia and the Northern Hungary. 


\section{Conclusion}

Based on the obtained results it can be concluded, however, not very suprisingly, that we have confirmed rising regional differences between the capital regions and their adjacent region and the rest of the regions in the case of both countries. Regional development does not take place in isolated space, interregional forces act between regions, affecting the mobility of production factors like migration of labour and capital. Capital regions tend to attract into its surroundings these production factors and thus contribute to increasing division in regional structure in the whole countries in terms of disparities.

Besides the territorial impact factors, regions are also affected by the factor of time. Over time, production factors adapt to changes in the market mechanism, but labour and also capital migrate to places depending on their potential product return. Workforce does not migrate only territorially but also vertically in labour productive scale. Thus, workers look for higher incomes and jobs which can offer them higher wages. During the study of analysis of structural changes we have noticed a substantial shift in vertical workforce migration from primary sector (agriculture) and also in some cases from the secondary sector (industry) into the tertiary sector (services) in case of both countries. In Slovakia, in case of industrial sectors, some regions denoted substantial growth in terms of employment, which evenly outpaces the employment growth on the national level, which reflects massive inflow of investments after accession of Slovakia into the EU. However, some regions, namely the ones located in the east of Slovakia, also denoted the decline in employment which reflects the rising division between the western and eastern part of Slovakia. The sector of services denoted growth in all regions which is in conformity with current employment trends in Europe. In Hungary, in case of industrial sectors, all regions denoted substantial decline in employment, and the drop evenly outpaces the change in national level, which reflects the difficult economic situation of Hungary during the analyzed period.

In the present macroeconomic environment and at current market conditions, regions of both countries are not suitable for providing services with high added value, which could bring the permanent and sustainable growth. The backbone of the economy is the production and sector of services is tightly bound to the primary and secondary sector. For regions, it is necessary to focus on their own endogenous factors located on their territory, develop interregional relations, namely in adjacent areas, and search for comparative advantages of their factors. Only in these cases we can reach stable, sustainable long-term growth without permanent outflow of production factors.

\section{References}

BELAJOVÁ, A. - FÁZIKOVÁ, M. 2005. Regionálna ekonomika. Nitra : SPU, 2005. ISBN 80- 8069-513-X.

CENTRE for Regional Studies, Hungarian Academy of Sicences. 1999. Regional processes and spatial structures in Hungary in the 1990's, Pécs, 1999. ISBN 9639052086.

ENYEDI, G. 1990. New Basis for Regional and Urban Policies in East-Central Europe, Pécs : Centre for Regional Studies of Hungarian Academy of Sciences.

EUROPEAN BANK for Reconstruction and Development. 2004. Transition report 2004. London. ISBN 1898802254.

EUROPEAN COMMISSION. European Institute for regional and local development institute for human sciences. 1995. Eastern and Central Europe 2000. Brussels. ISBN 92- 826-9547-6

GYORGYI, B. et al. 2005. Hungarian Spacesand Places : Patterns of Transition. Pécs, 2005. ISBN 9639052469.

KRUGMAN, P. R. - OBSTFELD, M. 1997: International economics: theory and policy. $4^{\text {th }}$ edition, Addison Wesley Longman, Inc., 1997. 766 p. ISBN 0-673-52497-3.

MACHLUP, F. 1990. Economic Semantics.Transaction Publishers. $2^{\text {nd }}$ edition, 1990, 404 p. ISBN 0887388361.

OECD Regional Outlook. 2011. Building resilient regions for stronger economies. 2011. [online]. Dostupné na internete: http://www.oecd.org/gov/regional-policy/49077205.pdf

OECD Regional Outlook. 2011. Building resilient regions for stronger economies. 2011. [online]. Dostupné na internete: http://www.oecd.org/gov/regional-policy/49075051.pdf

SVEJNAR, A. 2002. Labor Market Flexibility in Central and East Europe. In The William Davidson Institute, 2002.

STAM, W - ELFRING T. 2008. Entrepreneurial orientation and the performance of high-technology ventures: The moderating role of intra- and extraindustry social capital. In Academy of Management Journal, 2008, no. 51, p. 97-111.

UGRON, M. e. al. 1979. Basics of statistics. Bratislava : Alfa press, 1979. 390 p. ISBN 63-555-79.

\section{Contact adress:}

Ing. Martin Mariš, PhD., Slovak University of Agriculture in Nitra,Faculty ofEuropeanStudiesand RegionalDevelopment, Department Regional and Rural Development, Tr. Andreja Hlinku 2, 94976 Nitra, Slovak Republic, phone: +421 37 64145 62, e-mail: Martin.maris@uniag.sk 